\title{
Pharmacognostic Study of Sangkareho Root (Callicarpa longifolia Lam.) from Pelaihari, South Kalimantan
}

Fitriyanti *
Yusmalina
Rahmi Muthia
Department of Pharmacy, Sekolah
Tinggi Ilmu Kesehatan Borneo Lestari,
Banjarbaru, South Kalimantan,
Indonesia $\quad$ Keywords:
*email: fitriyantihudari@gmail.com
Callicarpa longifolia Lam
Pharmacognostic
Thin-layer chromatography

\begin{abstract}
Sangkareho (Callicarpa longifolia Lam.) is used traditionally by one of Kalimantan's indigenous tribes, the Dayak Tunjung tribe as a medicine for colds and inflammation, where the plant parts used are the roots. Considering its very potential prospects, research aimed at providing a scientific basis for plant pharmacognostic data needs to be carried out with qualitative methods. The qualitative examination is done by several methods including test identification of organoleptic, macroscopic, microscopic, and chemical compounds. Organoleptic test results showed that the roots have a light brown color, bitter and slightly spicy, and a rather pungent odor. Microscopic test results showed sangkareho root has a length of $\pm 90 \mathrm{~cm}$; width of $\pm 1 \mathrm{~cm}$; and for the form of a spear with a ride root system. Microscopic observations are found in the form of epidermal cells, exodermis, cortex, endodermis, bearing files, calcium oxalate crystals, and stone cells. The identification of chemical compounds showed positive results against alkaloids, flavonoids, saponins, and triterpenoids. The thin-layer chromatography profile shows four separate stains with eluent ethyl acetate : methanol : water in a ratio of $8: 2: 1$, respectively.
\end{abstract}

Received: February 20th 2020

Accepted: April 25th 2020

Published: May 21 2020

(C) 2020 Fitriyanti, Yusmalina, Rahmi Muthia. Published by Institute for Research and Community Services Universitas Muhammadiyah Palangkaraya. This is an Open Access article under the CC-BY-SA License (http://creativecommons.org/licenses/by-sa/4.0/). DOI: https://doi.org/10.33084/bjop.v3i2.1267

\section{INTRODUCTION}

Indonesia is a country that has enormous biodiversity potential. Geographically, Indonesia has many types of plants that can be used traditionally as medicines for various diseases (von Rintelen et al., 2017). One of them is the island of Borneo or also known as Kalimantan, which has the potential of traditional medicine knowledge by various tribes and is rich in useful plants (Khoo et al., 2016).

Sangkareho (Callicarpa longifolia Lam.) is one of the native plants of Borneo which belongs to the genus Callicarpa (Novaryatiin et al., 2018; Qamariah et al., 2016). This plant contains a source of natural compounds and can be used as traditional medicines (Harley et al., 2004). The Callicarpa genus is utilized by one of the indigenous tribes of Kalimantan, the Dayak Tunjung tribe (Setyowati, 2010). Callicarpa longifolia, also called "karehau", is traditionally used as a treatment for cold symptoms and inflammation of the roots, while the leaves are useful as a wet powder with analgesic, antiinflammatory, antimicrobe, and antioxidant activity (Handayani \& Natasia, 2018; Erwin et al., 2015).

Pharmacognostic studies are the first step in the standardization process of medicines derived from plants (Yuan et al., 2016). This research helps identify the nature and characteristics of a plant material. Identification and quality assurance of an ingredient are important prerequisites for ensuring plant quality that will contribute to safety and efficacy (Castillo et al., 2020; Ekor, 2013). 
According to previous research it was revealed that the leaves of C. longifolia with $70 \%$ ethanol extract had several secondary metabolite compounds such as flavonoids, tannins, saponins, and terpenoids (Supomo et al., 2016; Semiawan et al., 2015). However, research on the content of chemical compounds from the roots of C. longifolia plants especially those originating from South Kalimantan has never been done before, so researchers are interested in examining the pharmacognostic study of C. longifolia by organoleptic, macroscopic, microscopic, identification of groups of chemical compounds, and thin-layer chromatography (TLC). This pharmacognostic study is expected to be able to assist in identifying the content of efficacious compounds especially those found in the roots of the C. longifolia plant.

\section{MATERIALS AND METHODS}

\section{Plant material}

Callicarpa longifolia plant was collected from Pelaihari, South Kalimantan in the month of January 2018. The plant was identified by Laboratory of Pharmacognosy, Faculty of Mathematics and Natural Sciences, Universitas Lambung Mangkurat.

\section{Pharmacognostic study}

Coarse root powder of C. longifolia is used to study organoleptic, macroscopic, microscopic, phytochemical identification, and TLC profiles of C. longifolia ethanol extract (Supomo et al., 2016; Wulandari, 2011; Hanani, 2014; Gandjar \& Rohman, 2007; Puspadewi et al., 2013).

\section{RESULTS AND DISCUSSION}

\section{Organoleptic test}

Callicarpa longifolia root observed shape, color, taste, and odor based on five respondents' opinions. Organoleptic examination of fresh C. longifolia root color was light brown while the root simplicia was brown. Fresh roots and simplicia of C. longifolia has a bitter and some bitter taste, the taste is suspected to have an alkaloid and saponin compound as according to Harbone (2006), alkaloids and saponins have a bitter or bitter taste. The smell of fresh roots and simplicia of C. longifolia has a distinctive odor that is a rather pungent odor.

\section{Macroscopic characteristics}

Macroscopically, the fresh root of C. longifolia is the length around $\pm 90 \mathrm{~cm}$; the width of the C. longifolia root is around $\pm 1 \mathrm{~cm}$; and for the C. longifolia root form it has a spear shape (Tjitrosoepomo, 2005) with a tapering system, as presented in Figure 1.

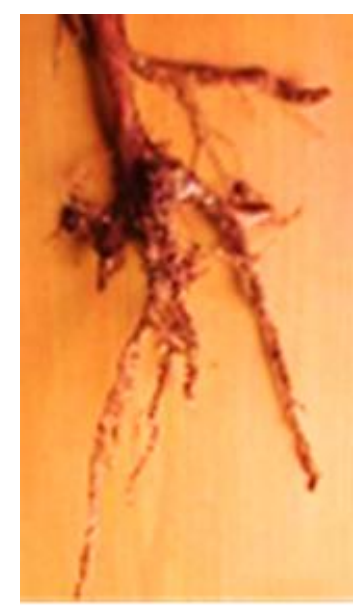

Figure 1. Callicarpa longifolia root

\section{Microscopic characteristics}

Based on microscopic anatomy at a $10 \times 10$ magnification including epidermis, exodermis, cortex, endodermis, transport file, and pith, as can be observed in Figure 2. At a magnification of $40 \times 10$ available stone cells and $\mathrm{Ca}$ oxalate crystal. In the anatomy of root powder with a magnification of $10 \times 10$ fibers have the epidermis and exodermis are the outermost part of the root, the epidermis consists of a tightly arranged cell membrane, which does not have space between cells. The function of the epidermis is to protect the underlying tissue (Javelle et al., 2011). Endodermis is the layer that separates the cortex with the central cylinder, the function of the endodermis is the part that is inserted by ground water 
into the ship. The cortex is composed of several layers of cells, which are close to the epidermal layer (Palmgren, 2018).

At the root of the transport beam system consists of xylem and phloem arranged alternately. The transportation file consists of xylem or a means of transportation used to transport food and nutrient extracts from the soil to the whole body of the plant, and phloem, which is a file that functions as a carrier of photosynthesis from the leaves to the entire body of the plant (Turner \& Sieburth, 2003). Pith is located between transport vessels that are in the parenchymal tissue. The function of the pith itself is used to store nutrients for plants, travel nutrients in the stems, branches, leaves and roots of plants. Stone cells (sclereids) is a network of sclerenchyma cells that are relatively round with a thick cell wall, this network serves to strengthen the body of the plant (Whitehill et al., 2016).

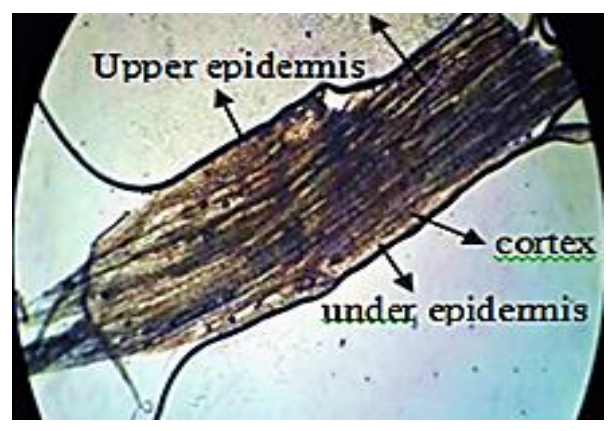

a

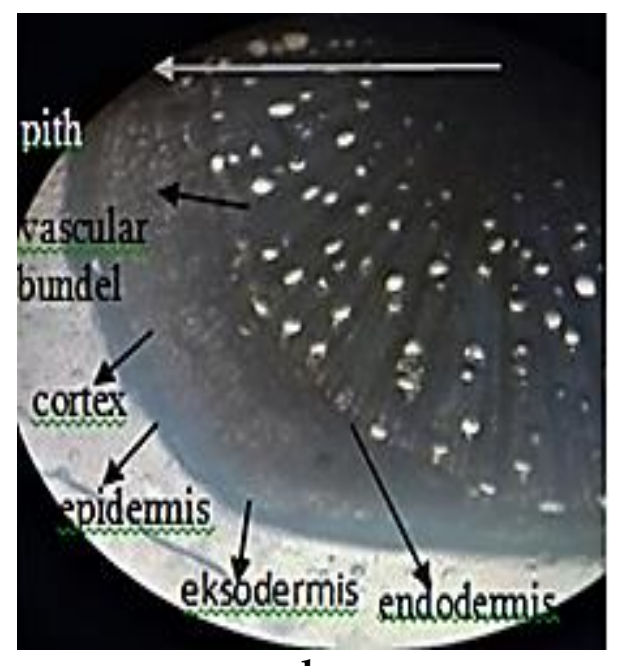

b

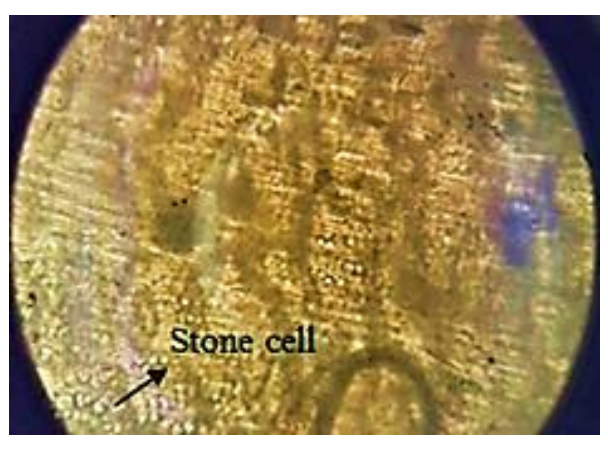

C

Figure 2. Microscopic fresh root of $C$. longifolia with magnitude of $10 \times 10(\mathbf{a})$ and $40 \times 10(\mathbf{b})$ with the appearance of a stone cell

(c)

Calcium oxalate crystal as can be seen in Figure 3 is indicated by black dots (Toolakou et al., 2016). The function of calcium oxalate crystal is as a protector for plants, because calcium oxalate can react allergically to animals that eat it. Fibers are sclerenkim tissue, consisting of cells that are elongated with thick and pointed-ended cell walls, which function as supporting tissues (Whitehill et al., 2016).

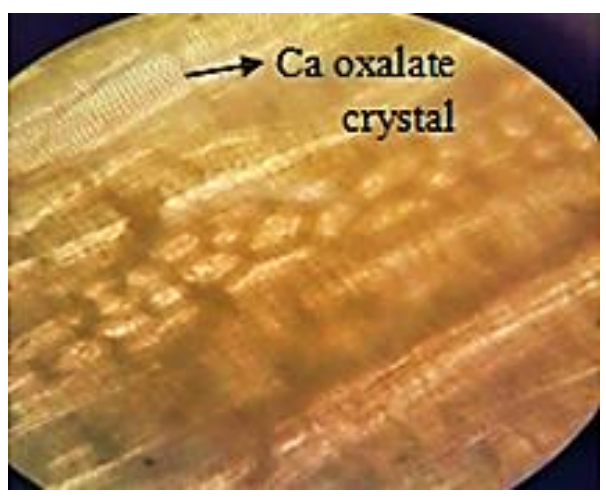

a

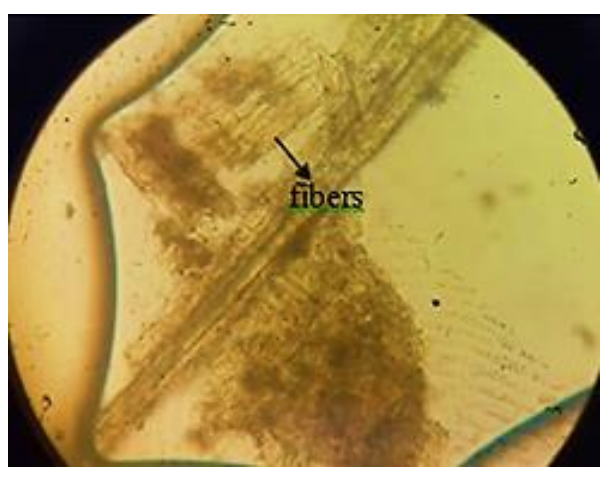

b

Figure 3. Microscopic powder of $C$. longifolia root with magnitude of $10 \times 10$ with the appearance of $\mathrm{Ca}$ oxalate crystals (a) and fibers (b) 


\section{Phytochemical screening}

Phytochemical screening of C. longifolia roots showed positive results on the presence of alkaloid, flavonoid, saponin, and triterpenoid compounds. These results are in line with previous studies reported by Ardhany et al. (2019) and Saputra (2016).

\section{Thin-layer chromatography profile}

Thin-layer chromatography results using ethyl acetate : methanol : water $(8: 2: 1)$ eluent provide good stain management and quite clearly separated. On observations using $\mathrm{UV}_{254} \mathrm{~nm}$ obtained three stains with the Rf value of $0.72 ; 0.61$; and 0.54 . Observation using $\mathrm{UV}_{366} \mathrm{~nm}$ appeared single white stain with Rf value of 0.54. Observation using $\mathrm{H}_{2} \mathrm{SO}_{4}$ stain viewer which was then heated in an oven obtained four stains with $\mathrm{Rf}$ value of $0.14 ; 0.54 ; 0.61$; and 0.72 . From the results of TLC profiles obtained four spots that showed about samples using eluent ethyl acetate : methanol : water $(8: 2: 1)$. For the value of $\mathrm{Rf}$ is in accordance with the range, while the value of Rf between 0.2-0.8 (Gandjar \& Rohman, 2007). The Rf value can be made to prove in identifying the composition. If the value of $\mathrm{Rf}$ has the same value, then the composition can be claimed to have the same or similar characteristics. Meanwhile, if the Rf value is different from the complement that can be claimed to represent a different composition (Kartini et al., 2020). Based on the description, seen from the TLC profile and $\operatorname{Rf}$ value of $70 \%$ ethanol extract of $C$. longifolia root with ethyl acetate eluent: methanol : water $(8: 2: 1)$. The eluent optimization is good for improvement, but for development it can be done by increasing the polarity of the eluent mixture used (Zhang et al., 2018). The TLC plate with multiple spotting views is presented in Figure 4, while a comparison of the Rf values obtained is presented in Table I.

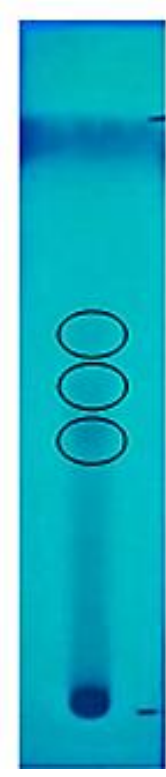

a

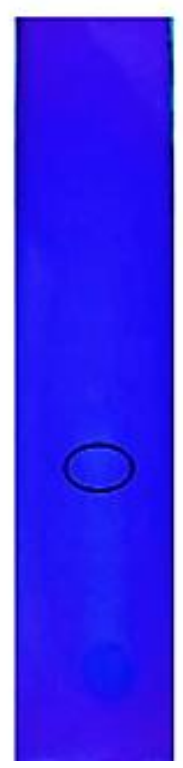

b

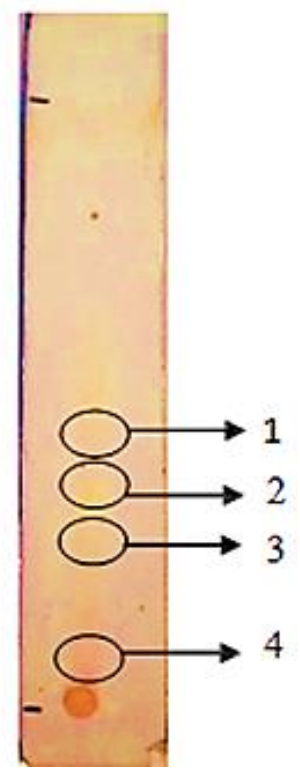

C
Figure 4. The TLC plate profile with $\mathrm{UV}_{254} \mathrm{~nm}(\mathbf{a}), \mathrm{UV}_{366} \mathrm{~nm}$ (b), and $\mathrm{H}_{2} \mathrm{SO}_{4}(\mathbf{c})$ stain viewer

Table I. The Rf value of TLC results with ethyl acetate : methanol : water $(8: 2: 1)$ eluent

\begin{tabular}{cccc}
\hline Stain Viewer & Spot & Rf & Color \\
\hline $\mathrm{UV}_{254} \mathrm{~nm}$ & 1 & 0.72 & Dark blue \\
& 2 & 0.61 & Dark blue \\
$\mathrm{UV}_{366} \mathrm{~nm}$ & 3 & 0.54 & Dark blue \\
$\mathrm{H}_{2} \mathrm{SO}_{4}$ & 1 & 0.45 & White \\
& 1 & 0.72 & Red \\
& 2 & 0.61 & Yellow \\
& 3 & 0.54 & Dark Yellow \\
& 4 & 0.14 & Dark Yellow \\
\hline
\end{tabular}

\section{CONCLUSION}

Characteristics of $C$. longifolia root there are several examinations consisting of organoleptic examination of C. longifolia root has a light brown root color, a bitter taste and a bit bland and a rather pungent characteristic odor. Macroscopic examination of $C$. longifolia root has a length of approximately $\pm 90 \mathrm{~cm}$; width of approximately $\pm 1 \mathrm{~cm}$; and for the shape of the roots of $C$. longifolia is a spear with a tapered root system. In microscopic examination of the identified fragments the cell forms are epidermis, exodermis, cortex, endodermis, transport beam, calcium oxalate crystal, and stone cells. From the results of identification of chemical compounds, the compounds contained in C. longifolia root are alkaloids, flavonoids, 
saponins, and triterpenoids. The results of the TLC profile showed four stains on the plate using eluent ethyl acetate : methanol : water $(8: 2: 1)$.

\section{ACKNOWLEDGMENT}

The authors would like to thank Department of Pharmacy Sekolah Tinggi Ilmu Kesehatan Borneo Lestari for providing the support.

\section{REFERENCES}

Ardhany, S.D., Chusna, N., Utar, Z., Zakaria, Z., \& Pascalo, B. (2019). Antidiarrheal activity of ethanolic extract of leaves of Sangkareho (Callicarpa longifolia Lam) from Central Kalimantan. Letters in Applied NanoBioScience, 8(4), 739-743. doi:10.33263/LIANBS84.739742

Castillo, L., Baltodano, E., Ramirez, N., Vargas, R., \& Hanley, G. (2020). Design of Experiments Assessment for the Determination of Moisture Content in Five Herbal Raw Materials Contained in Tea Products. Borneo Journal of Pharmacy, 3(1), 22-35. doi:10.33084/bjop.v3i1.1236

Ekor, M. (2013). The growing use of herbal medicines: issues relating to adverse reactions and challenges in monitoring safety. Frontiers in Pharmacology, 4, 177. doi:10.3389/fphar.2013.00177

Erwin, E., Nisa, R.A., \& Daniel, D. (2015). Phytochemical Test, Toxicity and Antioxidant Activity Leaves Kerehau (Callicarpa longifolia Lam.) With DPPH Method. Jurnal Akta Kimia Indonesia (Indonesia Chimica Acta), 8(1), 52-59. doi:10.20956/ica.v8i1.2481

Gandjar, I.G. \& Rohman, A. (2007). Kimia Farmasi Analisis. Yogyakarta, Indonesia: Pustaka Pelajar.

Hanani, E. (2014). Analisis Fitokimia. Jakarta, Indonesia: Penerbit Buku Kedokteran EGC.

Handayani, R. \& Natasia, G. (2018). Uji Daya Hambat Ekstrak Etanol Daun Sangkareho (Callicarpa longifolia Lam.) terhadap Escherichia coli. Jurnal Surya Medika (JSM), 3(2), 54-61. doi:10.33084/jsm.v3i2.98
Harborne, J.B. (2006). Metode Fitokimia, Penuntun cara modern menganalisis Tumbuhan. Bandung, Indonesia: ITB Press.

Harley, R.M., Atkins, S., Budantsev, A.L., Cantino, P.D., Conn, B.J., Grayer, R., de Kok, R., Krestovskaja, T., Morales, R., Paton, A.J., Ryding, O., Upson, \& Labiatae, T. In: Kadereit, J.W., Ed. (2004). Flowering Plants, Dicotyledons: Lamiales, except Acanthaceae, including Avicenniaceae, The Families and Genera of Vascular Plants. New York, U.S.: Springer. doi:10.1007/978-3-64218617-2

Javelle, M., Vernoud, V., Rogowsky, P.M., \& Ingram, G.C. (2011). Epidermis: the formation and functions of a fundamental plant tissue. The New Phytologist, 189(1), 17-39. doi:10.1111/j.1469-8137.2010.03514.x

Kartini, K., Dewi, E.R., Achmad, F., Jayani, N.I.E., Hadiyat, M.A., \& Avanti, C. (2020). Thin Layer Chromatography Fingerprinting and Clustering of Orthosiphon stamineus Benth. from Different Origins. Pharmacognosy Journal, 12(1), 79-87. doi:10.5530/pj.2020.12.13

Khoo, H.E., Azlan, A., Kong, K.W., \& Ismail, A. (2016). Phytochemicals and Medicinal Properties of Indigenous Tropical Fruits with Potential for Commercial Development. Evidence-Based Complementary and Alternative Medicine, 2016, 7591951. doi:10.1155/2016/7591951

Novaryatiin, S., Sari, A. A., \& Mulyani, E. (2018). Antibacterial Activity of Ethanolic Extract of Sangkareho (Callicarpa longifolia Lam.) against Staphylococcus epidermidis. Borneo Journal of Pharmacy, 1(2), 85-88. doi:10.33084/bjop.v1i2.427

Palmgren, M. (2018). Plant epithelia: What is the role of the mortar in the wall? PLoS Biology, 16(12), 3000073. doi:10.1371/journal.pbio.3000073

Puspadewi, R., Adirestuti, P, \& Menawati, R. (2013). Khasiat Umbi Bawang Dayak (Eleutherine palmifolia (L.) Merr.) Sebagai Herbal Antimikroba Kulit. Kartika: Jurnal Imiah Farmasi, 1(1), 31-37. doi:10.26874/kjif.v1i1.21

Qamariah, N., Handayani, R., \& Khadafi, A. (2016). Pemanfaatan Tumbuhan Sangkareho (Callicarpa longifolia Lam) Asal Kalimantan Tengah sebagai Obat Tradisional. Jurnal Surya 
Medika (JSM), 2(1), $\quad 14-22$. doi:10.33084/jsm.v2i1.364

von Rintelen, K., Arida, E., \& Häuser, C. (2017). A review of biodiversity-related issues and challenges in megadiverse Indonesia and other Southeast Asian countries. Research Ideas and Outcomes, 3 , 20860. doi:10.3897/rio.3.e20860

Saputra, A.K. (2016). Uji Identifikasi Farmakognostik Tumbuhan Sangkareho (Callicarpa longifolia Lam.) asal Kalimantan Tengah. In: Pratama, M.R.F., Ed. (2016). Prosiding Seminar Nasional Ilmu Kesehatan SNiK. Palangka Raya, Indonesia: Universitas Muhammadiyah Palangkaraya.

Semiawan, F., Ahmad, I., \& Masruhim, M.A. (2015). Aktivitas Antiinflamasi Ekstrak Daun Kerehau (Callicarpa longifolia L.). Jurnal Sains dan Kesehatan, 1(1), 1-4. doi:10.25026/jsk.v1i1.7

Setyowati, F.M. (2010). Etnofarmakologi Dan Pemakaian Tanaman Obat Suku Dayak Tunjung Di Kalimantan Timur. Media Penelitian dan Pengembangan Kesehatan, 20(3), 104-112.

Supomo, Supriningrum, R., \& Junaid, R. (2016). Karakterisasi Dan Skrining Fitokimia Daun Kerehau (Callicarpa longifolia Lamk.). Jurnal Kimia Mulawarman, 13(2), 89-96.

Tjitrosoepomo, G. (2005). Morfologi Tumbuhan. Yogyakarta, Indonesia: Gadjah Mada University Press.

Toolakou, G., Giannopoulos, A., Nikolopoulos, D., Bresta, P., Dotsika, E., Orkoula, M.G., Kontoyannis, C.G., Fasseas, C., Liakopoulos, G., Klapa, M.I., \& Karabourniotis, G. (2016). Alarm Photosynthesis: Calcium Oxalate Crystals as an Internal CO2 Source in Plants. Plant Physiology, 171(4), 2577-2585. doi:10.1104/pp.16.00111

Turner, S. \& Sieburth, L.E. (2003). Vascular Patterning. The Arabidopsis Book, 2, 0073. doi:10.1199/tab.0073

Whitehill, J.G., Henderson, H., Schuetz, M., Skyba, O., Yuen, M.M., King, J., Samuels, A.L., Mansfield, S.D., \& Bohlmann, J. (2016). Histology and cell wall biochemistry of stone cells in the physical defence of conifers against insects. Plant, Cell $\mathcal{E}$ Environment, 39(8), 1646-1661. doi:10.1111/pce.12654
Wulandari, L. (2011). Kromatografi Lapis Tipis. Jember, Indonesia: Taman Kampus Presindo.

Yuan, H., Ma, Q., Ye, L., \& Piao, G. (2016). The Traditional Medicine and Modern Medicine from Natural Products. Molecules, 21(5), 559. doi:10.3390/molecules21050559

Zhang, Q.W., Lin, L.G., \& Ye, W.C. (2018). Techniques for extraction and isolation of natural products: a comprehensive review. Chinese Medicine, 13, 20. doi:10.1186/s13020-018-0177-x 